\title{
OBITUARY
}

\section{Johannes Joseph van Rood: pioneer in immuno-genetics (7 April 1926-21 July 2017)}

Bone Marrow Transplantation (2017) 52, 1485-1486; doi:10.1038/ bmt.2017.221; published online 9 October 2017

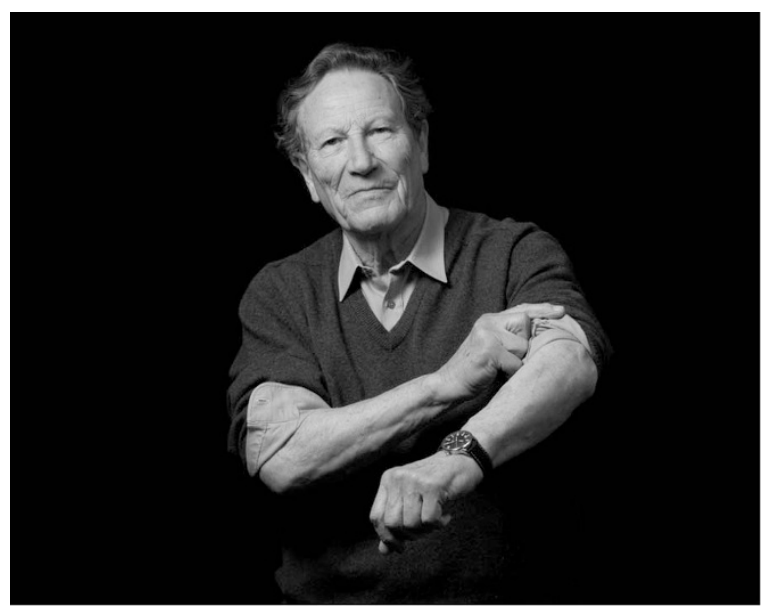

Jon van Rood was one of the smartest, most remarkable people we have met. His death on 21 July 2017, age 91, ended one of the great rivalries, later friendships (with the late Dirk van Bekkum) in Dutch haematology and transplant biology. Their relationship reminds us of Kahneman and Tversky (Nobel laureates in economics), two intellectual giants from a small country with an outsized imprint on science.

It is difficult to overstate Jon's, as he was widely-called in the usual informal Dutch manner, impact on the world of haematopoietic cell transplantation. Here is just one small example. In 2014, we held a festschrift honoring Professor Paul Terasaki. One distinguished speaker, Sir Walter Bodmer, spoke on the evolution of our understanding of the HLA-system. Sir Walter showed several formulae from van Rood's PhD thesis, which had greatly influenced his work and mentioned that Jon was the first person to use computers to analyze HLA-serotyping data. Computers at that time were the size of a small house and the data had to be entered on IBM punch card. RPG FaceTime'd Jon from his mobile phone and showed him the scene on-stage. He was pleased.

Jon van Rood was born on 7 April 1926 in Scheveningen, the Netherlands. He studied medicine at the University of Leiden and in 1957 became an internist. During his training, even before becoming an internist, he was appointed head of the blood bank of the Leiden University Hospital, a position he kept for 39 years. In 1958 , he made his first of many seminal observations in a multiparous woman who developed fever, chills and vomiting after receiving a blood transfusion. She had never received a blood transfusion before, and van Rood hypothesized the reaction was related to her prior pregnancies. In a Nature publication, he reported anti-leukocyte antibodies in sera of parous women. In 1962 , he received his doctoral degree (cum laude). His thesis was entitled 'Leukocyte Typing, A Method and its Application'. After receiving his doctorate, he worked for a year in the Immunology Department of the Public Health Research Institute in New York, before returning to Leiden, where he was appointed Professor of Internal Medicine in 1969. In 1976, he became Director of the Department of Immunohematology and Blood Transfusion of the Leiden University Hospital, retiring in 1991. He still kept an office and continued those admirable Dutch traits of, speaking frankly, arguing vociferously when he thought someone was wrong and did not suffer fools gladly (2nd Corinthians 11:19). 'I published my best paper when I was 80 years old' he once said with a grin.

Jon's contributions to transplant immunology and immunegenetics are too numerous to list. In addition to his basic science discoveries, he always kept a clinician's view toward the potential applications of these discoveries. For example, in our field, he and his colleagues unraveled the potential role of non-inherited maternal antigens and $\mathrm{H}$-Y-associated antigens. And much more.

Jon was an internationalist who fostered scientific and clinical collaborations in many arenas. In 1967, he helped set up Eurotransplant, in 1970 Europdonor (now Matchis) and in 1985 the European Foundation for Immunogenetics, which he chaired. Jon was a founder of the European Group for Blood and Marrow Transplantation (EBMT), and a strong early supporter and founding Advisory Board member of the International Bone Marrow Transplant Registry (now Centre for International Blood and Marrow Research (CIBMTR)) where he was a close friend of Professors Mortimer Bortin and Mary Horowitz. He later became a Counselor. He was also a founder, co-founder of the Bone Marrow Donors Worldwide (BMDW) and the World Marrow Donors Association (WMDA). Professor van Rood was a member of many international organizations. In 1978, he became a member of the Royal Netherlands Academy of Arts and Sciences. He has received many well-deserved honors, including eight honorary doctorates and the Wolf and Robert Koch prizes amongst others, in recognition of his scientific contributions.

In RPG's youth, in New York City, many men smoked cigars. Often these were Dutch Masters, which came in a cardboard box with Rembrandt's 1662 painting De Staalmeesters (The Syndics of the Drapers' Guild) on the cover. (This was, of course, a marketing ploy dreamed up by a Madison Avenue agency. The cigars were made in the United States and had nothing whatever to do with Holland). RPG was always impressed by Jon who with his red van Dyke beard looked exactly like the distinguished men on the cigar box cover. Some years ago, he introduced his wife Laura to Jon saying: 'Please meet my colleague Professor Jon van Rood, a prototype Dutchman'. He responded politely: 'Actually no, I'm part Jewish'. He followed with a remarkable story of how the Nazis knew of him and searched for him in Leiden after their invasion of Holland. Jon hid in the basement of his father's home, sneaking out during the day to attend medical school, avoiding checkpoints and returning to his sanctuary to study at night. He sat in a leather chair positioned opposite a subterranean window, which allowed him to see people passing by to help relieve his isolation. One night, he rebelled leaving the basement to attend a party with medical school classmates. When he returned, he found several pieces of shrapnel embedded in the back of the chair. Clearly, he would have been killed that night had he stayed in hiding. God works in strange ways. Perhaps? 
Jon was a quick thinker. Once he and Professor Gerhard Opelz were invited to Paul and Hisako Terasaki's Bel Air home shortly after Paul had become an unintentional multi-millionaire (see Bone Marrow Transplantation. 2016 51: 621-22). Gerhard brought flowers for Hisako and Jon, a small copy of a Rembrandt etching in a box for Paul. However, before dinner Paul took them on a home tour, during which he showed them an original Rembrandt etching. Hisako got the flowers and Gerhard, the Rembrandt etching.

After retiring in 1991, Jon remained scientifically active. He maintained strong personal ties with many of his former colleagues and remained a loyal guest at all departmental seminars. At the same time, he was an inspiring mentor for many students and colleagues. Jon died in Leewarden, the Netherlands. This seems prophetic as Leewarden is the start and finish of the famed $200 \mathrm{~km}$ Elfstedentocht (eleven cities tour), in which ice skaters race on frozen canals. (Kanti Rai and RPG tried in 1983 collapsing after first kilometer). Jan ran a beautiful life's race covering the globe, not just northern Holland and now returns to receive the victor's laurels. He is survived by his wife Sacha, three children and six grandchildren.

This obituary is also published in Leukemia (doi:10.1038/leu. 2017.278).

\section{CONFLICT OF INTEREST}

The authors declare no conflict of interest.

W Fibbe ${ }^{1}$ and RP Gale ${ }^{2}$

${ }^{1}$ Leiden University Medical Centre, Leiden, The Netherlands and ${ }^{2}$ Haematology Research Centre, Hammersmith Hospital, Imperial College London, London, UK E-mail: robertpetergale@gmail.com 